\title{
Apart from traditional design approaches: Peter Opsvik's path
}

Leading an investigation in product design about children's domestic furniture, a research for a case study on evolutive chairs brought us to an approach which can point out ways for a better and more adequate practice in Design.

The work of Peter Opsvik (n. 1939), a Norwegian designer, searches for a balance between traditional materials, innovative ergonomic approaches and ecological and ethical concerns. Finding elements which define Opsvik's practice and thinking, we may conclude his theories, apart from traditional design approaches, add a valuable study in human nature and lead to a better and more complete attitude as a designer.

keywords traditional design, innovation, human factors and ergonomics, ethics and ecodesign, product attachment

\section{Introduction}

Our overall objective is the creation of more suitable furniture for children, leading to extended product life cycles and contributing to sustainable development. Namely, through a project of a chair which can follow child's growth from 6 months up to 7 years old and guarantees physical and visual comfort, without being overpriced nor "disposable". Following a methodology based on literary review and case study, a research was conducted in order to attain information about the Tripp Trapp $\circledast$ chair from Stokke $\circledast$, a Norwegian company based in Alesund. Tripp Trapp $®$ was our main example of what an evolutive chair could be. A piece of furniture which can follow child's growth nearly from birth (with a system of extra elements or accessories), to an adult stage. When searching for the author, we came across with an extensive work based on the most interesting theories about human posture and movement, under a name: Peter Opsvik.

Opsvik was born on the west coast of Norway in 1939. He studied Design at the Bergen College of Applied Art and at the State College of Applied Art, in Oslo (Ryan, 2000). He worked as an industrial designer at Tandberg Radio Factory, Oslo. In 1967 he won a scholarship to go to a London design studio and two years later, he attended Volkwangschule Für Gestaltung in Essen, Germany. In 1970, Peter Opsvik decided to work as a freelance designer. He runs a design studio in Oslo along with other colleagues since 1984 .

His innovative views about human posture and behaviour, which we will investigate further in this article, were put to practice in an impressive number of chair designs. More than 35 pieces, produced and distributed by several Scandinavian furniture companies and almost an equal number of small edition pieces reflecting artistic approaches, which he calls Art/ 
With this study, we aim to discover ways to reach a design practice more adequate to human nature and to human environment. Traditional design approaches need to evolve and embrace new challenges, for a more healthy and happy mankind. The objective of this paper on Opsvik's work is to understand how innovative his views are and if they have grown apart from traditional design practices.

\section{Swim against the tide or lead to a better path}

Firstly, let's identify what we call the tide as a general and dominant design thinking and practice. Design is primarily an art based discipline and even industrial design is mainly taught in art schools (Green and Jordan, 1999, p. 2), depending a lot in the artist/ designer's individuality and creativity. Traditionally seen as an artist, the designer in public eye takes all the credit for a whole process which involves many other disciplines (Forty, 2005, p. 241). Often concerned with aesthetics, rather than with function, many designers fail to focus on what really matters: human welfare. And even if some may follow the motto form follows function, they don't examine human behaviour extensively. To be able to design a good object for someone, one needs to study the user in its whole dimension. We need to understand what is comfort and what can we do to provide it to the user. Human factors and ergonomics' importance in design processes today is undeniable, accepting that "...the paramount objective of HFE (Human Factors and Ergonomics) is to understand interactions between people and everything that surrounds us and based on such knowledge to optimize the human well-being and overall system performance." (Karwowski, 2012, p. 5). According to HFES (Human Factors and Ergonomics Society), the function of ergonomics on the technical group product design is to develop useful, safe and desirable products, applying the principles and methods of human factors, consumer research and industrial design to ensure the product's success in the marketplace.

Ergonomics traditionally searches for the ideal posture, based on anthropometric data and physical and physiological studies, overlooking our constant need for movement (Opsvik, 2013).

Opsvik doesn't deny the artistic dimension of Design, but sees it as only one part of the question. He adds a lot of research in human nature, which other designers overlook. He sets himself into an observer role, which he plays with devotion, trying to understand human beings in its essence - a nomad one. Human body is destined to variation and movement. Observing humans and how they interact with surrounding environments is extremely important. Much interested in sitting, Opsvik studies our body's evolution and its constant need for motion. Well adapted furniture is essential, for it's a kind of third skin we can have, being clothes our second skin and architecture our fourth.

"What I am suggesting is that the chairs we "wear" for long periods of time should be neither as soft and flexible as our clothes, nor as hard and inflexible as our buildings; rather, the chair should work as an intermediary between the dynamic body and our static architectural surroundings." (Opsvik, 2013).

One of his first works as an independent designer is Tripp Trapp $®$ chair, launched in 1972 by Stokke $®$. He faced a problem with his two-year-old son, by not having in the market, a chair suitable for his age and size. He wanted to make him part of familiar gathering over meals. Then he designed one. An evolutive chair which can easily follow child's growth (Fig. 1). 


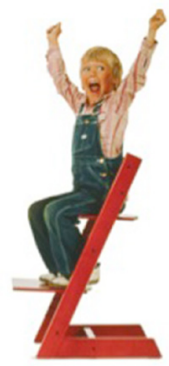

Figure 1.

Peter Opsvik's son

in a Tripp Trapp ${ }$

chair (1972),

Photo:

Peter Opsvik

http://www.opsvik.

no/downloads/

stokke.

Two plywood boards change position as the child grows, evolving from seat and footrest for baby or child, to a seat for teen or adult provided from child's footrest. In the year 2000, around three million Tripp Trapp $®$ chairs have been sold worldwide and it holds a $90 \%$ share of the market in Norway. It is seen as more than just a chair, as so many people have grown up with it. Its presence is accepted just as easily as a door or window in any home (Ryan, 2000). In Portugal unfortunately, there are very few examples of evolutive chairs, distribution is rare and prices are high.

But Opsvik doesn't just try to follow human growth, he thinks the key to comfort is not support people in static positions, as the majority of designers do, is to support them in several positions, so that they can move and change position (Opsvik, 2009, p. 37). For Opsvik "...the best posture is always the next one.", so there's not an ideal posture like we are trained to follow in anthropometric data books. Any (so called) perfect posture is doomed to be uncomfortable after a while. Variety is a positive thing. Monotony is always negative and sedentary situations are harmful to people's health both physical and mental. He thinks adults need encouragement and support to continue moving but children need security and that's how he explains the solid structure and sturdy seat on Tripp Trapp $®$ chairs without tilting or rocking (Opsvik, 2009, p. 162).

One more innovative approach from Peter Opsvik has to do with concerns about the human body as a hole, giving feet and legs the necessary attention, in contradiction with traditional ergonomists. For they are much more concerned with hands and arms, studying interaction with working systems. Taking as an example the Thatsit balans $₫$ chair, which provides comfort in several positions. One might say, these chairs look much like rocking chairs, for they have an implicit movement in its formal and functional characteristics. The concern with feet, knee and leg position is notorious, providing rest in many different postures (Fig. 2).

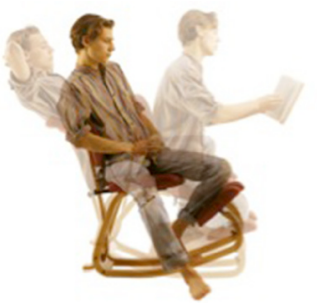

Figure 2.

Peter Opsvik's Thatsit balans® chair (1991), Photo: Varier. http://www.opsvik. no/downloads/ varier. 
Figure 3.

Peter Opsvik on its Globe Garden chair (re-launched in 2014), Photo: Peter Opsvik. http://www.opsvik. no/downloads/ moment
Opsvik launched a project with Stokke $\AA^{\circledR}$ in 1985 which was more like a message than a piece of furniture, presented in his book with the motto "Our ancestors lived in trees". He created a range of chairs intended to be for public spaces, called Garden - it looks more like a tree than a seat. He states the idea behind the chair is not to produce a practical seat or even a piece of sculpture, but to express the designer's opinions on the rules of sitting and "we should be more concerned about our body signal and less concerned with convention" (Opsvik, 1996, p. 8). It was re-launched by Swedish company Moment AB in 2014 under the name Globe Garden (Fig. 3). He's inventing new ways of sitting. When reflecting on consumption, Opsvik reveals its freedom towards styles and trends.

"when the planet is overwhelmed by products and users for an endless number of articles, it can appear a paradox to develop new products. Nevertheless, I am convinced that products will enjoy a longer existence where devotion, farsightedness and thoughtfulness contribute to their development, than those products governed by fashion and trends" (Opsvik, 1996, p. 7).

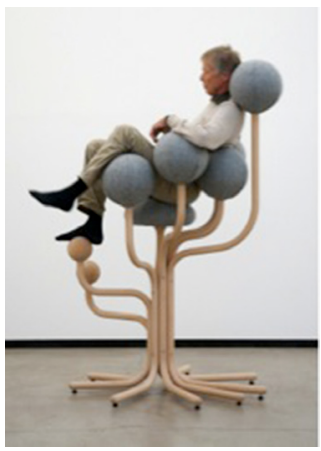

For what concerns sustainability, Opsvik has a long-term vision, creating objects more adapted to human nature with traditional materials, as environmental issues are part of his concerns. Energy and production resources are along with material choices, vital to a sustainable development (Papanek, 1995, p. 31). Besides considering functionality is what gives the product most of its value and status (Ryan, 2000), his choice on materials is very important too. Tripp Trapp $®$ chair, along with most of his designed products, is produced only with wood harvested in sustainable forests. Beech and oak from Europe and walnut from the U.S., in solid and laminated wood are Opsvik's choices for this chair.

Another aspect about sustainability of Opsvik's work is that, by designing multifunctional chairs, he puts to practice his views on producing less objects but better objects. His constant observation of human nature enables him to sum up a lot of functionalities in a single chair, so people don't need a big number of chairs each for a purpose (working, resting, eating, reading), when a single well designed chair guarantees well-being in a lot of different positions.

Opsvik refers on his book Rethinking Sitting, "Timeless" as one of his environmental ideas behind the Actulum chair, defining it as "The visual design will hopefully remain popular for many years, without appearing old-fashioned." (Opsvik, 2009, p. 62). He is also concerned about what kind of objects we leave for future generations, for the great amount of 
technological and disposable paraphernalia that exists nowadays, will not reach them. But a well-made wooden furniture piece or a silver spoon, properly held, will last generations, growing old nicely and accumulating and expressing life stories over the years.

According to Borjesson's studies, product attachment is a precondition for products' sustainability, pleasantness is an affect and designing pleasurable products can create a bond between object and user (Borjesson, 2008). Besides sensual experience, context (social and cultural backgrounds, which are prone to change) also influences pleasure.

As a result, durable attachment is difficult to achieve (Jordan, 2000). But when it comes to meaning, cultural differences can disappear if verbal and visual communication are combined (Pöppel, 2007). Possession of material goods enables the subject to "incorporate" the meanings that are signified to them by a given object (Fromm, 2005, p. 40 ) and emotional bonding with objects also through a process of identification may be a key for more suitable and sustainable materiality. As Chapman states, "waste" is the result of broken (emotional) relationships (Chapman, 2005).

\section{Conclusion}

Peter Opsvik seems to swim against the tide when we speak about traditional design approaches. He moves the scope to ergonomics and human observation as a basis for a designer's work. He tries to balance the functional and expressive/artistic aspects of an object, outside the flow of styles and trends. Not only he has a pioneering design practice focusing on ergonomics, he also innovates in that field with his theories of constant movement.

Opsvik's views on movement and variation are passionately put to practice and his devotion on studying human evolution and interaction with the surrounding environment is outstanding. We consider therefore, Peter Opsvik to be an indisputable example of design practice which has grown apart from tradition and leads to an optimized progress in Design where human factors are decisive. This example deserves proper interest by design schools and design historians around the world, because this isn't just about a case in Scandinavian design. It's about searching the essence of Design.

\section{References}

Borjesson, K. (2009) Affective Sustainability. Is this what timelessness really means? in: Undisciplined! Design Research Society Conference 2008. Sheffield, UK, 16-19 July 2008.

Chapman, J. (2005) "Emotionally Durable Design - Objects, Experiences \& Empathy". London: Earthscan.

Forty, A. (2005) Objects of Desire: Design and Society since 1750, 8th edition, London: Thames \& Hudson.

Green, W. S. and Jordan, P. W. (1999) Human Factors in Product Design: Current Practice and Future Trends, London: Taylor and Francis.

Jordan, P.W. (2000) Designing Pleasurable Products. London: Taylor \& Francis.

Karwowski, W. (2012), "The discipline of Human Factors and Ergonomics". in: Handbook of Human Factors and Ergonomics. Salvendy, Gavriel (Ed.). Hoboken, NJ: Wiley. 
theme 6

open strand

Opsvik, P. (2009) Rethinking Sitting, New York: W. W. Norton.

Opsvik, P. (2013) Sitting Philosophy, [Online], Available: http://www.opsvik.no/reflections/ sitting-philosophy [28 Dec 2013].

Papanek, V. (1995) Arquitectura e Design: Ecologia e Ética, Lisboa: Edições 70.

Pöppel, E. (2007) A Toolbox for Thinking - an essay. COGNITIVE SEMIOTICS, Fall 2007, pp. 8-24.

Ryan, N. (2000) Norwegian Design: The Work of Furniture Designer Peter Opsvik, Dublin: The National College of Art \& Design [Online], Available: http://archive.is/OeSA [28 Dec 2013].

West Norway Museum of Applied Art (ed.) (1996) Peter Opsvik: Open Doors, Bergen: West Norway Museum of Applied Art. 